\title{
Human chlamydial infections: persistence, prevalence, and outlook for the future
}

\author{
Judith A. Whittum-Hudson ${ }^{\mathrm{a}}$, Alan P. Hudson ${ }^{\mathrm{b}}$ \\ a Professor of Immunology, Department of Immunology and Microbiology, Wayne State University School of Medicine, \\ Gordon H. Scott Hall, 540 East Canfield Avenue, Detroit, Michigan 48201, USA \\ b Professor of Microbiology, Department of Immunology and Microbiology, Wayne State University School of Medicine, \\ Gordon H. Scott Hall, 540 East Canfield Avenue, Detroit, Michigan 48201, USA
}

Impressionnés par l'émergence de nouvelles maladies, nous oublions les agents pathogènes déjà installés. Pourtant, certains d'entre eux causent toujours misère et souffrance à des millions de personnes, et constituent des entraves majeures au développement. Cet article nous rappelle que les Chlamydia sont responsables de cécités, de stérilités, de maladies vasculaires, articulaires ou respiratoires... Il nous apprend que les avancées récentes de la connaissance biologique offrent à nos sociétés de nouvelles perspectives pour comprendre et alléger le fardeau imposé par nos pathogènes.

La Rédaction

\section{Keywords:}

Chlamydia trachomatis; Chlamydia pneumoniae; infectious disease; health care costs; anti-chlamydial therapies; vaccine development

\section{Mots-clés :}

Chlamydia trachomatis ; Chlamydia pneumoniae; maladies infectieuses; coût des soins médicaux; thérapies anti-chlamydia ; développement de vaccins

\begin{abstract}
Infectious diseases have imposed a profound burden on mankind throughout the history of our species. Importantly, many of the microbe-induced diseases that have plagued us for millennia remain of significant concern in industrialized nations, developing nations, or both, including tuberculosis, cholera, and others. Bacterial pathogens of the Order Chlamydiales have caused disease in both humans and domestic animals for thousands of years, but it is only recently that we have begun to fully understand the subtle and complex long-term consequences of human chlamydial infections. In this article, we describe the current understanding of the biology and pathobiology of the human pathogens Chlamydia trachomatis and C. pneumoniae. We discuss the acute diseases that these important organisms cause, and more importantly, we describe the known and suspected chronic disease sequelae that follow those primary infections. Finally, we explore the economic, social, and human consequences of chlamydial infections, and we propose strategies for ameliorating or obviating those consequences.
\end{abstract}

Résumé - Maladies infectieuses dues aux Chlamydia. Pourquoi cette persistance et quel avenir? L'humanité a été lourdement marquée par les maladies infectieuses tout au long de son histoire. Il faut bien aujourd'hui constater que les pathologies provoquées par des microbes et affligeant l'homme depuis des millénaires demeurent toujours une préoccupation majeure des pays en développement comme des pays industrialisés. C'est en particulier le cas des maladies que causent les bactéries de l'ordre des Chlamydiales chez les hommes et leurs animaux domestiques : cécité, pneumonie, stérilité... Depuis peu, nous commençons à comprendre les relations subtiles et complexes entre l'hôte et le pathogène, et donc à évaluer les conséquences à longue échéance des infections. Cet article fait un point des connaissances de biologie et de pathologie à propos de Chlamydia trachomatis et C. pneumoniae. À partir de la présentation des maladies provoquées par ces deux microorganismes, nous examinons les séquelles chroniques, connues ou suspectées, de chacune des infections primaires : il semble bien que l'hôte humain et ses pathogènes microbiens aient vécu une longue «association » qui a façonné les deux partenaires. Nous envisageons enfin le contexte et les conséquences économiques et sociales des infections par les Chlamydia pour mobiliser les connaissances actuelles et suggérer des stratégies d'évitement ou de soulagement.

Corresponding author:

A.P. Hudson, ahudson@med.wayne.edu 


\section{Introduction}

Over the course of human history, infectious diseases have imposed a significant burden of misery, and very often mortality, on mankind. From the devastating epidemic in Athens during the 5th century BC, through the Black Death in 14th century China, Central Asia and Europe, to the current pandemic of HIV/AIDS (human immunodeficiency virus/acquired immune deficiency syndrome) and beyond, the unpredictable and often catastrophic appearances of pathogenic microorganisms in human populations have ended the lives of millions and powerfully influenced the economic and social structures of affected groups. Indeed, some pandemics have altered the fate of nations and thus the course of history (Watts, 1997). Cataclysmic episodes of infectious disease arise and subside irregularly over relatively circumscribed historic time periods, but many microbe-induced diseases have been the constant companions of our species. For example, typhus, cholera, and others, although less devastating over brief periods than bubonic plague or smallpox, have visited misery and death on us over many millennia, and several of these diseases remain of significant concern today. Drug-resistant bacterial pathogens continue to emerge, a particularly unsettling situation in the case of tuberculosis. Equally unsettling is the emergence of new infectious diseases such as SARS (severe acute respiratory syndrome), and the potential weaponization of natural or, more probably, genetically altered viral or bacterial pathogens.

Over the last two centuries we have learned a great deal regarding the organisms that cause human disease. That is, we know which pathogens elicit which specific diseases, and research often has shown us in detail how they do so. This and other information has lead to the development of anti-microbial drugs and vaccines which can effectively combat and/or prevent many infectious diseases. Yet while a natural pandemic of plague due to Yersinia pestis is unlikely today, tuberculosis and cholera remain important daily concerns in several parts of the world. Moreover, syphilis, various pneumonias, scarlet fever, and a host of other diseases, although treatable, remain major health problems in both underdeveloped nations and the industrialized world (e.g., Hook and Peeling, 2004).

Diseases caused by bacterial pathogens of the Order Chlamydiales have been our companions for millennia. For example, we know that blinding trachoma, one of the clinical entities caused by these organisms, has had a long association with mankind because this disease is accurately described in the Ebers papyrus, a collected medical text written by Egyptian physicians nearly 4 millennia ago (West, 2004). Greek physicians also provided written descriptions of how treatment of trachoma was accomplished in the ancient world, and they gave accurate descriptions of the physical consequences that follow ocular infection with Chlamydia (West, 2004; see also below). Our laboratories have studied the biology and pathobiology of the Chlamydia for many years, and over the last two decades it has become clear from our own work and that of others that these organisms can and do elicit disease in far more subtle ways than were previously understood. In this article we discuss longknown, recently-identified, and still-suspected clinical consequences of human chlamydial infection. We place those consequences into a context of the human and economic tolls exacted by such infections, and we suggest means for minimizing those tolls in the future ${ }^{1}$.

\section{Chlamydia species and chlamydial infections}

For purposes of the discussion following it is useful to describe the diseases the chlamydiae engender, and to provide some insight into the biology and pathobiology of these unusual organisms. Nine chlamydial species are recognized by most workers in the field. All are obligate intracellular eubacterial parasites of human or animal cells, and all are pathogenic to their various hosts. Seven of those species infect domestic and other animals to cause economically important diseases; one of the seven, C. psittaci, a pathogen of birds, can cause a severe zoonotic infection (e.g., Heddema et al., 2003; see also below). Two chlamydial species, Chlamydia trachomatis and C. pneumoniae, are human pathogens; although both can infect lower mammals in experimental situations, no animal reservoir is known for either of these pathogens. The former is the etiologic agent for blinding trachoma, a disease which remains the most prevalent cause of preventable blindness world-wide (e.g., West, 2004). C. trachomatis also is the most prevalent sexually transmitted bacterial pathogen in the United States and most other developed countries (Schachter, 1999). C. pneumoniae is a respiratory pathogen responsible for community-acquired pneumonia (Grayston, 1992).

All chlamydial infections are acquired via mucosal surfaces. For C. trachomatis, the sites of primary infection are the ocular conjunctivae (trachoma) or the epithelial surfaces of the urogenital system (sexually-transmitted infection). C. pneumoniae is acquired via the oral and nasal mucosa. As mentioned, all chlamydial species are obligate intracellular parasites, and completion of their normal developmental cycle thus requires that they infect a eukaryotic host cell. That cycle is biphasic (Fig. 1). In the first phase, the infectious extracellular form of the

\footnotetext{
1 This article presents a de novo synthesis of ideas and therapeutic suggestions based on recent research results from the authors' laboratories and those of other investigators. The text has not been presented elsewhere in any form.
} 


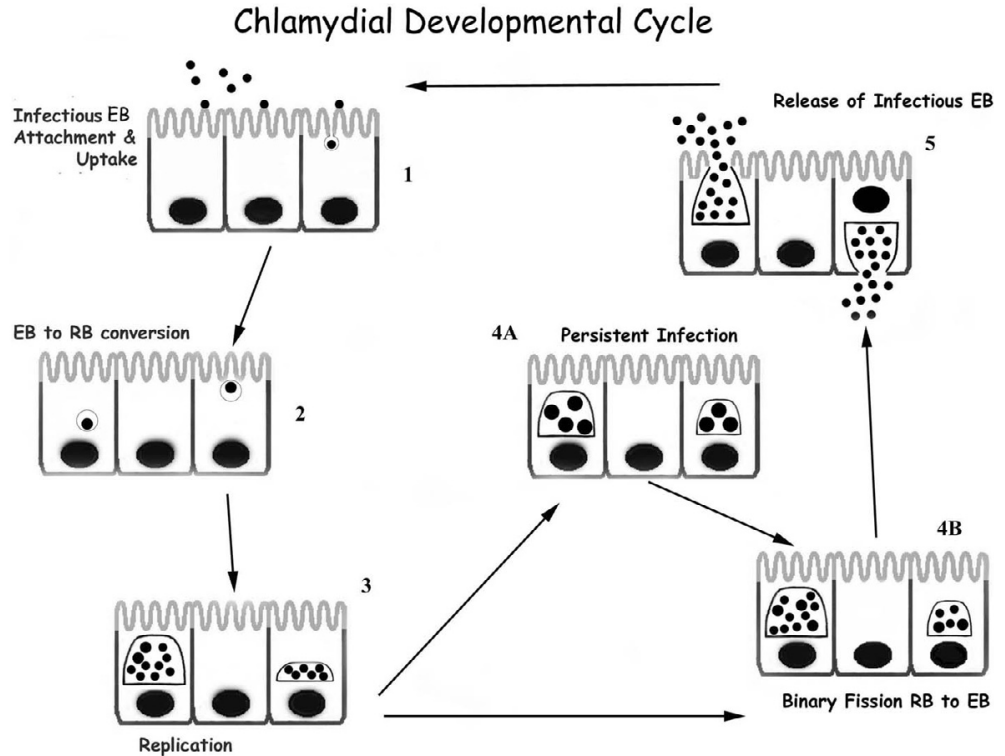

Fig. 1. The biphasic developmental cycle of Chlamydia trachomatis and Chlamydia (Chlamydophila) pneumoniae. In (1), elementary bodies (EB) attach to their host cell, and once inside that host cell they differentiate into the reticulate body (RB) form (2). Each RB then undergoes cell division (3), and may proceed to enter the persistent infection state $(4 \mathrm{~A})$, or to de-differentiation to the EB state (4B) prior to release from the host cell (5) to perpetuate infection. (Adapted from Whittum-Hudson, 2005; used with permission.) organism, the elementary body, locates and attaches to an appropriate host cell. The latter are usually epithelial or epithelia-like cells, but many other cell types can be infected. After attachment, the organism is brought into a membrane-bound cytoplasmic vesicle within which it reorganizes into the metabolically active form, the reticulate body. During this second, intracellular phase, reticulate bodies undergo several rounds of cell division, at the termination of which most reorganize back to the elementary body form. Newly-formed elementary bodies then are released to further propagate infection by lysis of the host cell (Hatch, 1999).

At their sites of primary infection, C. trachomatis and C. pneumoniae each elicit a strong inflammatory response in the host. In addition to inflammation, other important aspects of the pathology engendered during primary infection are a function of the biology of the organisms, specifically lysis of host cells for elementary body release at the end of the developmental cycle. In trachoma, for example, repeated ocular infections by C. trachomatis cause increasing destruction of the epithelial cell layer on the inside of the eyelid (the ocular conjunctiva), which over time results in scarring (Schachter, 1999; West, 2004). Repeated episodes of ocular infection, and thus conjunctival scarring, eventually turn the eyelid inward, placing the eyelashes onto the cornea. Blinking with lashes turned inward causes accumulating damage to the cornea via abrasion from the lashes, in turn obscuring vision and promoting infection by other pathogens. Genital infection by C. trachomatis attacks the epithelial cell layer of the urethra, causing painful and/or difficult urination, or the cervix, often causing severe discomfort (Schachter, 1999; Ward, 1999). C. trachomatis infecting the cervix can progress up the reproductive tract to cause pelvic inflammatory disease (PID) and salpingitis (Ward, 1999). The organism also causes occlusion of the fallopian tubes by scarring, which can lead to sterility or to ectopic pregnancy (Ward, 1999; Mårdh, 2004a). Some recent evidence indicates that this organism is associated with cervical cancer (Anttila et al., 2001). Importantly, several studies have demonstrated that genital infection with $C$. trachomatis predisposes to acquisition of other sexually transmitted pathogens, particularly HIV-1, the etiologic agent of AIDS (e.g., Nusbaum et al., 2004). Pulmonary infection by C. pneumoniae accounts for $10 \%$ or more of community-acquired pneumonia and perhaps $5-10 \%$ of bronchitis and sinusitis (Hahn et al., 2002). Importantly, recent reports have associated this pathogen with more severe pulmonary diseases, including asthmatic bronchitis and chronic obstructive pulmonary disease (COPD) (e.g., Clementsen et al., 2002).

Many studies have shown that both $C$. trachomatis and C. pneumoniae can and do disseminate widely from their sites of primary infection, and when they do so these organisms can take up long-term residence at distant anatomic locations (e.g., Moazed et al., 1998). At sites of their chronic disseminated residence, both organisms enter an unusual biologic state designated "persistence" (Hogan et al., 2004). In this state they do not complete the developmental cycle, and they display unusual morphologic, transcriptional, and other properties (e.g., Villareal et al., 2002). While we do not fully understand how persistently-infecting chlamydiae elicit pathology in all cases, it is clear that they can engender a strong immunopathogenic response, which in turn contributes to various chronic diseases. Disseminated, persistentlyinfecting $C$. trachomatis is the causative agent for a chronic painful inflammatory arthritis, and we showed that the 
Table 1. Possible sequelae of chlamydial infections*.

\begin{tabular}{ll}
\hline C. trachomatis & Salpingitis \\
& Pelvic inflammatory disease (PID) \\
& Fallopian tubal occlusion/ectopic pregnancy \\
& Inflammatory (reactive) arthritis \\
& Cervical carcinoma? \\
& \\
C. pneumoniae & Sarcoidosis \\
& Chronic obstructive pulmonary disease (COPD) \\
& Atherosclerosis \\
& Coronary disease \\
& Inflammatory arthritis \\
& Giant cell (temporal) arteritis \\
& Multiple sclerosis? \\
& Sporadic (late-onset) Alzheimer's disease? \\
\hline
\end{tabular}

* See the text for details and relevant references.

organism is in the persistent state in the blocked fallopian tubules of patients with severe fertility problems (Gérard et al., 1998; Whittum-Hudson et al., 2004, 2005a). Disseminated infection by C. pneumoniae has been linked to a surprising panel of non-respiratory diseases, including atherosclerosis (e.g., Belland et al., 2004), inflammatory arthritis (e.g., Whittum-Hudson et al., 2005b), multiple sclerosis (Sriram et al., 1999), and Alzheimer's disease (Balin et al., 1998) (Tab. 1). These associations are controversial, but they remain a focus of active investigation.

\section{The prevalence and economic impact of chlamydial infections}

\section{Genital Chlamydia trachomatis infections}

Sexually-transmitted diseases are among the most common illnesses world-wide, and C. trachomatis is almost certainly the most common sexually-transmitted bacterial infection among them. One report estimated that in 1995, 89 million people between 15 and 45 years of age globally had a chlamydial infection of the urogenital tract (Gerbase et al., 1998). In the United States, genital infections by $C$. trachomatis must be reported to the Centers for Disease Control (CDC) by each of the 50 states and the District of Columbia. In 2003, the most recent year for which complete data are available, 877,478 new cases of C. trachomatis infection were reported by the states and the District together (Centers for Disease Control and Prevention, 2004). Estimates from various sources range as high as 4 million active cases of genital $C$. trachomatis at any one time in the US. As indicated above, genital infections by $C$. trachomatis are of particular concern for women due to the potential long-term reproductive sequelae that they can engender. CDC data for 2003 indicate that the prevalence of infection among women is $5.9 \%$ overall for 15-24 year olds screened at family planning clinics among the 50 states, the District of Columbia, and

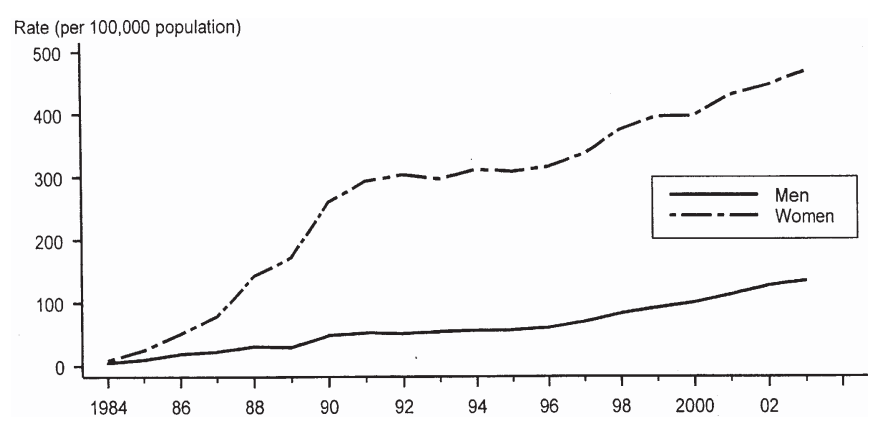

Fig. 2. Genital infection by Chlamydia trachomatis in the United States, rates presented by sex. (Adapted from Centers for Disease Control and Prevention, 2004; used with permission.)

elsewhere; that number is higher among women entering job training programs (median state-specific prevalence $9.9 \%$ ), and among young women entering juvenile correctional facilities (median facility screening positivity $15.9 \%$ ) (Centers for Disease Control and Prevention, 2004). Disturbingly, the prevalence of genital chlamydial infection among women, and men as well, is increasing (Fig. 2), although some of the observed increase is a result of better reporting, improved screening methods, and so on. We note that genital infection by C. trachomatis has been linked to reproductive problems in men as well as in women (e.g., Krause and Bohring, 2003). Overall, because genital chlamydial infection in women is frequently asymptomatic, and because not all women (and fewer men) are screened routinely for the organism, our and others' strong suspicion is that the actual prevalence and incidence of such infections is far higher than those cited here from official sources. This contention is supported by a study of more than 10,000 female army recruits who were screened for $C$. trachomatis using a sensitive and reliable method; prevalence among this wide cross-section of women was 9.2\% (Howell et al., 1999).

Estimates of the prevalence of genital chlamydial infection in Europe appear to be equivalent, or even somewhat higher, than those for the US. For example, a recent study showed a prevalence of $5.9 \%$ for genital C. trachomatis infection among men 17-35 years of age in Ireland (Powell et al., 2004); a similar prevalence was identified among young women screened in three cities in Scotland. In England, where a National Chlamydia Screening Program was initiated in 2002 for men and women under 25 years of age, the first year's data indicated a $10.1 \%$ prevalence among women tested and a $13.3 \%$ prevalence among men (LaMontagne et al., 2004). In Eastern Europe, estimates of genital chlamydial infection among young women give values of $4.5 \%$ or higher (e.g., Masata et al., 2004). Prevalence in Europe and the US generally decreases with increasing age in both women and men. Australia apparently has no organized nationwide screening program for genital chlamydial infection, 
but available studies indicate prevalence rates similar to those for Europe and the US (Debattista et al., 2002).

Data for genital chlamydial infection in other regions of the world are sparse. A study of genital C. trachomatis in relation to infection with human papilloma virus (HPV) in women in Bogota, Columbia, indicated a rate of about $5 \%$, with a somewhat higher prevalence identified in women with the viral infection (Molano et al., 2003). In a study of young women in Brazil, the overall prevalence of genital C. trachomatis infection was about $12 \%$ among the sexually-active, a rate many-fold higher than that shown for gonorrhea in the same population (Miranda et al., 2004). One study of chlamydial infection in China identified the prevalence of genital infection as $2.6 \%$ for women and $2.1 \%$ for men, a rate again far higher than that for gonorrhea in the same study population (Parish et al., 2003). Similarly, a report of genital C. trachomatis infection in India indicated an overall prevalence of 1.1\%. However, $2.4 \%$ of the study population displayed antibodies against $C$. trachomatis, and essentially all individuals tested for anti-chlamydial antibodies alone or directly for infection were asymptomatic (Joyee et al., 2004). Given the large populations of China and India these prevalence rates represent a huge number of infected individuals; for a number of reasons the estimates also are probably lower than actual values. Information concerning genital chlamydial infection is especially difficult to obtain for underdeveloped countries or regions. Estimates for Africa, though, are striking - as many as 15 million new cases per year over the continent (Gerbase and Mertens, 1998). This represents an enormous number of individuals at increased risk for acquisition of other sexually transmitted pathogens; it unquestionably is a contributing factor to the high prevalence of HIV/AIDS on that continent.

Detailed and reliable estimates of the overall costs of genital chlamydial infections to the health care systems involved and national economies in general are rare. One recent study in the US estimated that for eight of the most common sexually-transmitted infections (including genital herpes virus, HPV, gonorrhea, Chlamydia, others) among 15-24 year olds, the total health care bill was $\$ 6.5$ billion in year 2000 US dollars (Chesson et al., 2004); of that total, the largest proportions were attributable to HIV and HPV. Chlamydial infections were estimated extremely conservatively to have cost more than \$248 million; this number included the costs for treatment of epididymitis in men and PID in women, but not other costs such as those attributable to ectopic pregnancy, lost productivity, treatment for arthritis, etc. Further, contact tracing is required in the US for patients with a newly-diagnosed genital chlamydial infection, and the considerable costs pertaining to this expensive and timeconsuming process for every new patient are never included in published estimates. Although we have not been able to identify reliable general data for the costs of such infections in Europe or elsewhere, it seems unlikely that they would be significantly lower than those in the US. To our knowledge, no estimates are available concerning the cost of treating primary $C$. trachomatis infections, or their frequent reproductive sequelae in women, in Africa or elsewhere in the developing world. Clearly, comprehensive surveillance systems must be established throughout Europe, North America, and in the developing world, as argued by several authors, if the enormous number of genital chlamydial infections is to be brought under control (e.g., Mårdh, 2004b). Moreover, aggressive public campaigns must be undertaken to promote awareness of the long-term dangers of genital C. trachomatis infection. It will be critically important, of course, to design and implement surveillance systems and public health awareness campaigns in a manner consistent with the social, religious, and cultural structures of the targeted population groups (see also below).

\section{Ocular C. trachomatis infections}

In an important sense, trachoma is an economicallybased disease; i.e., it exists primarily in populations living under conditions of low income and poor hygiene. Because of improvements in public sanitation and the availability of clean water supplies, trachoma largely disappeared in developed nations during the 20th century, although it still is present among native populations in Australia and elsewhere (see below). Trachoma remains a significant disease in rural regions of many parts of the world, including the Middle East, Africa, southwest Asia, and the Indian subcontinent. Indeed in the developing world, trachoma is still the primary cause of treatable/preventable blindness (Mabey et al., 2003; West, 2004). Within affected countries, trachoma often exists in isolated pockets. For example, the disease is endemic in native tribes living in the rain forests of Brazil, but it is rare in urban centers of that country (Alves et al., 2002). This is also the case for Australia; while the disease has long been eliminated from urban areas, it remains endemic in some aboriginal populations (Taylor, 2001). Estimates of the prevalence of the disease world-wide suggest that nearly six million individuals currently are blind from trachoma, and perhaps twice that number are at significant risk for blindness (West, 2004); as many as 150 million people world-wide are affected in some way by the disease (Kumaresan and Mecaskey, 2003). Sadly, some reports have pointed out that authorities in more than one developing nation consider trachoma a low health priority (e.g., Kasi and Gilani, 2004). As might be expected, defining the overall economic impact of trachoma either world-wide or within any given country is problematic. However, one estimate gives a figure of US \$2.9 billion annual loss overall in productivity due to this disease 
(Kumaresan and Mecaskey, 2003). Although now confined primarily to the developing world, trachoma remains a disease of major importance, and it currently is a focus of intensive eradication efforts (see below).

\section{C. pneumoniae infections}

As briefly outlined, C. pneumoniae is a respiratory pathogen responsible for a large proportion of cases of community-acquired pneumonia (Grayston, 1992). The incidence and prevalence of pneumonias attributable to this organism either world-wide or in any specific country or region are unknown, since no organized national or supra-national screening programs targeting C. pneumoniae infection exist to date. Limited studies of the prevalence of seropositivity to C. pneumoniae are available from some locales, however. These reports generally indicate that antibodies against the organism are rare in children under 10 years of age, although some studies indicate that about $10 \%$ of children hospitalized with pneumonia possess antibodies against the organism (e.g., Schmidt et al., 2003; Michelow et al., 2004). The incidence of seroconversion rises steeply after childhood. In the US about 50\% of 20 year olds show evidence of prior infection (CDC website); by the seventh decade, seropositivity rates approach $80-90 \%$ (Leinonen, 1993).

High rates of seropositivity also have been reported in various population groups and contexts in Europe (e.g., Garbino et al., 2002), Canada (Marrie et al., 2003), Taiwan (Lin et al., 2004), and elsewhere (e.g., Shimizu et al., 2002). Importantly, C. pneumoniae has been associated with several more severe pulmonary diseases, including sarcoidosis, COPD, and others (e.g., Hahn et al., 2002). It is not clear at this point how many cases of these or other serious respiratory diseases might be attributable to the organism; more research is required to assess this and other related questions. Similarly, no estimates are available concerning the overall costs to health care systems of C. pneumoniae-induced respiratory diseases, or concerning the productivity losses due to those diseases. Given the high levels of adult seropositivity to $C$. pneumoniae observed in all studies, those costs must be substantial.

\section{Sequelae to C. trachomatis and C. pneumoniae infections}

As indicated, both C. trachomatis and C. pneumoniae can disseminate widely from their sites of primary infection, and when they do so they can engender significant long-term disease consequences. For the most part, those consequences result from a powerful immunopathogenic response to the organisms, as well as from the terminal host cell lysis/scarring at the end of the developmental cycle. The most important sequelae to genital C. trachomatis infection include PID, salpingitis, occlusion of the fallopian tubules, and other fertility-abolishing or diminishing problems in women; epididymitis can follow genital infection in men. Recent estimates indicate that about $8 \%$ of women with lower genital tract infection with C. trachomatis progress to PID; this number appears to account for fully half of all PID cases (Honey and Templeton, 2002). As importantly, nearly two thirds of women with infertility due to occluded fallopian tubes show antibodies against this organism; $C$. trachomatis may be the causative agent in up to $40 \%$ of ectopic pregnancies (Honey and Templeton, 2002). Other reports indicate that genital $C$. trachomatis is the most common cause of acute salpingitis, and that perhaps $25 \%$ of women with the acute disease become infertile (Guaschino and De Seta, 2000). Disturbingly, the incidence of new cases of PID and other reproductive problems due to genital chlamydial infection is high among urban young women in the US (e.g., Kelly et al., 2004) and in Europe (e.g., Grio et al., 2004).

Genital infection with C. trachomatis also can elicit a painful inflammatory arthritis in both men and women, and studies from our group and others indicate that a similar arthritis can follow C. pneumoniae infection (Whittum-Hudson et al., 2005a,b for review). The prevalence of acute C. trachomatis-induced arthritis has not been firmly established, but conservative estimates from the United States and elsewhere suggest it to be in the range of $5-10 \%$ of individuals with a documented prior genital infection with the organism (e.g., Rich et al., 1996; Soderlin et al., 2002). C. pneumoniae is somewhat less common in joint samples from patients with acute inflammatory arthritis than is C. trachomatis (Whittum-Hudson et al., 2005a,b). The prevalence estimate given here for arthritis induced by the latter is certainly an underestimate, since many patients (mainly women) have asymptomatic chlamydial infections of the urogenital system and thus are not diagnosed. Importantly, about half the number of patients who develop acute Chlamydiainduced arthritis progress to chronic disease (WhittumHudson et al., 2005a,b); conservatively, this included about 21,000 individuals in year 2002 (our calculation). We could find no estimate of the costs or economic losses resulting from lost productivity due to either acute or chronic Chlamydia-induced arthritis, but as with the overall costs related to many other forms of arthritis it is unquestionably substantial in both developed and developing nations.

In addition to arthritis, a number of other potential long-term and serious sequelae have been associated with infection by C. pneumoniae, including late-onset Alzheimer's disease, multiple sclerosis, giant cell arteritis, and others (Balin et al., 1998; Sriram et al., 1999; Swanborg et al., 2003) (Tab. 1); again, such associations remain controversial. Currently, it is not clear whether the association of this organism with these and other diseases 
is etiologic or exacerbatory, but in either case the epidemiologic and economic consequences are enormous. For example, it has been estimated that more than 4 million individuals currently suffer from late-onset Alzheimer's disease in the United States, with many more affected in Europe and elsewhere (e.g., Keefover, 1996). It is difficult to calculate the overall costs of care for patients with dementia due to Alzheimer's disease because much of that care is provided by unpaid family members. However, a recent estimate of the total costs for Alzheimer's patient care in California exceeded $\$ 23$ billion (US) for the year 2000 alone, and that cost was predicted to rise to more than $\$ 42$ billion by 2020 (Fox et al., 2001). Estimates of those costs from other nations appear to be congruent (e.g., Beeri et al., 2002; Rigaud et al., 2003). Similarly, estimates of the prevalence of multiple sclerosis in the US vary from $240 / 100,000$ to $710 / 100,000$ depending on the populations surveyed; available estimates of disease prevalence in European countries are somewhat lower but still significant (e.g., Sarasoja et al., 2004; Ragonese et al., 2004). The economic burden for long-term care of individuals suffering from multiple sclerosis is extremely high (e.g., Amato et al., 2002).

Cardiovascular disease is the leading cause of death in essentially all developed nations. In the late 1980's, a group in Finland published a landmark study indicating an association between C. pneumoniae infection and heart disease (Saikku et al., 1988). This association is now reasonably well-accepted in the medical and scientific communities, and it is particularly focused on atherosclerosis, a critical contributing factor to cardiovascular disease (reviewed in Belland et al., 2004; Campbell and Kuo, 2004). The organism has been identified in atherosclerotic plaques by several standard screening techniques and by many independent laboratories (Ciervo et al., 2003). Importantly a biochemical mechanism by which C. pneumoniae may contribute to plaque formation has been defined (Kalayoglu and Byrne, 1998a,b). As a leading cause of death and incapacity in developed nations, cardiovascular disease imposes an enormous burden on the health care systems of all those countries. For just one example, a recent study from the Netherlands indicated that the cost of treatment for a single affected individual can be as high as $€ 380,000$ (Groot et al., 2004). This does not include the costs of productivity losses attributable to affected individuals. Thus, it is perfectly possible that C. pneumoniae infection alone may be responsible for an exceptionally large proportion of health care costs in developed nations.

\section{Human diseases caused by or linked to other chlamydial species}

Diseases caused by C. trachomatis and C. pneumoniae represent the most prevalent, and therefore the best-studied, examples of human chlamydial infection. However, other chlamydial species are known to elicit pathology in humans. As indicated above, C. psittaci is a pathogen of birds that can cause an often severe zoonotic disease. The disease, designated psittacosis or ornithosis, is frequently although not universally pulmonary and can be acquired either from domestic or wild birds (e.g., Heddema et al., 2003; Telfer et al., 2005); person-to-person transmission also has been reported (Ito et al., 2002). Although the disease is not especially common in developed countries, it occurs frequently enough, and is severe enough, that a recent compendium was issued describing standard measures required for the control of human and avian (domestic) infections by this organism (Smith et al., 2005). We could identify no source of information providing insight into the prevalence of ornithosis in developing nations.

Interestingly, recent studies have identified an increasing and rather surprising diversity of previously unknown Chlamydia-like species (e.g., Corsaro et al., 2003 for review). Many of these studies have identified organisms related to the well-described human and animal pathogens using 16S rDNA sequence analyses, and two of the new species, Parachlamydia acanthamoebae and Simkania negevensis, are environmental organisms which have been associated with human pulmonary infections (Corsaro and Venditti, 2004 for review). As the name implies, the former organism infects free-living amoebae in the environment, and it has been shown to infect and multiply within human monocyte/macrophages (Greub et al., 2003a); some data suggest that the organism may be common, and overtly pathogenic, in institutionalized intensive care patients exposed to high levels of aerosols (Greub et al., 2003b). As with P. acanthamoebae, $S$. negevensis has been associated with respiratory infections, including bronchitis in infants and children and community-acquired pneumonia in adults (e.g., Johnsen et al., 2005). The organism has been identified in drinking water in Israel, and a very recent study indicated that, as for C. pneumoniae, the prevalence of infection with the organism increases with increasing age (Kahane et al., 2004; Yamaguchi et al., 2005). Much remains to be learned concerning the biology, environmental distribution, and pathogenic potential of these newly described organisms.

\section{Problems and prospects}

\section{Treatments for chlamydial infections}

Effective treatments for active urogenital and ocular infections by $C$. trachomatis are available in the form of various antimicrobials. The standard treatment for urogenital infection with $C$. trachomatis is a course of doxycycline or erythromycin, or a single dose of azithromycin, 
and these have proved to be effective in eradicating actively-growing organisms (Tobin et al., 2004); treatment with azithromycin has proved reasonably effective for active pulmonary C. pneumoniae infection. Many studies indicate, however, that these and other antimicrobial drugs are ineffective against persistent chlamydial infections (see below), and as mentioned neither C. trachomatis nor $C$. pneumoniae requires an animal reservoir for maintenance. Thus, the distribution of active and persistent chlamydial infections in any given human population must be assessed before large-scale treatment programs can be designed appropriately.

In an effort to achieve global elimination of blinding trachoma by 2020, the World Health Organization has instituted an international effort based on a program designated SAFE (see West, 2004) that includes: Surgical repair of damaged eyelids, Antibiotic treatment to reduce transmission of $C$. trachomatis and the progression to trachoma in affected individuals, a program to increase Facial cleanliness in affected populations to reduce carriage and transmission of the organism, and improvement of the Environment in terms of community public health in affected areas. Each of these aspects of the program is being adapted in its details to the local social, cultural, economic, and other conditions of the people targeted, and thus the SAFE program should reduce trachoma significantly. However, it is critical to recognize that ultimate success for this program will require a long-term commitment by the relevant governments, pharmaceutical companies, deliverers of healthcare, and the communities involved. With the exception of antibiotic treatment, this type of approach is not appropriate for eradication of other chlamydial diseases because the latter are not closely linked to socioeconomic elements, nor are they considered endemic. Thus, development of an effective Chlamydia vaccine remains important (see below).

Unlike treatment of active C. trachomatis or C. pneumoniae infections, antimicrobial treatment of persistent infections by either organism is problematic. For example, Chlamydia of either species infecting joint tissues in arthritis patients respond poorly or not at all to standard treatment with a single antibiotic because they reside in those tissues in the persistent, rather than the activelygrowing, state (Whittum-Hudson et al., 2004, 2005a,b for review). We note that one recent preliminary study reported some success in treating patients with putative Chlamydia-induced arthritis with a combination antibiotic therapy (Carter et al., 2004). In the case of atherosclerosis, it is not clear whether C. pneumoniae resides in vessel tissues in the persistent or actively-growing form or some mixture of each, but large-scale antibiotic trials have failed to show improvement in patients with aortic or other plaques (Grayston et al., 2005). Similarly for late-onset Alzheimer's disease, one small antibiotic trial failed to show improvement in patient cognitive function (Loeb et al., 2004). Clearly, a good deal more effort must be expended to understand why persistent chlamydiae do not respond, or respond so poorly, to powerful and otherwise effective anti-microbials. Moreover, it will be important to learn how we might coax these organisms from the persistent state back to the actively-growing state, in which antibiotics are effective.

Efficacy and other details relating to anti-microbial treatment of pulmonary or other infections by environmental Chlamydia-like species remain to be established. Strain differentiation among these organisms is relatively primitive at this point, and as mentioned, the prevalence of human infections with the organisms has not been determined in any given population; also, it is not clear whether Parachlamydia or Simkania can generate persistent infections, whether they respond reliably to current antibiotics and if so which ones, etc. It will be critical to determine the environmental distribution of these emerging pathogens so that eradication efforts can be appropriately structured and targeted.

\section{Vaccines}

The immunopathogenesis of chlamydial infection results from interactions between Chlamydia-derived products and host responses to them. These interactions have been studied for years, but despite enormous effort and investment a protective Chlamydia vaccine has yet to be taken to clinical trials. To date, most vaccines have targeted the major outer membrane protein of Chlamydia (Longbottom, 2003 for review). Because this protein is serovar- and species-specific, a successful vaccine may require inclusion of multiple antigens in a complex cocktail to enhance the protective capacity. Our own studies with an anti-idiotypic antibody vaccine which mimics a genusspecific antigen expressed by all chlamydial species (the glycolipid exoantigen) showed protection against experimental ocular (Whittum-Hudson et al., 1996) and genital (Whittum-Hudson et al., 2001; Whittum-Hudson, 1999) C. trachomatis infections. From the perspective that blinding trachoma, acute inclusion conjunctivitis, and other Chlamydia-associated diseases often are chronic and may represent sustained presence of organism and associated inflammation, an anti-chlamydial vaccine remains a major goal (de la Maza and Peterson, 2002; Moxon and Rappuoli, 2002). Indeed, a protective vaccine would have enormous world-wide public health and socioeconomic benefits. In the absence of any one key vaccine candidate target, however, solutions to the economic costs of worldwide vaccine distribution are premature. Some economic issues relating to trachoma vaccines have been discussed (Frick et al., 2004), and these may be useful in modeling the economics of pan-Chlamydia vaccines. 


\section{Conclusions}

In the 1960's a US Surgeon General made an infamously premature comment to the effect that the age of infectious diseases had ended. Soon thereafter it was demonstrated that while some strains of C. trachomatis are responsible for trachoma, several other strains are important in sexually transmitted disease, and the suite of clinical entities attributable to this chlamydial species and others since that time has grown significantly. Importantly, our understanding of the means by which Chlamydia elicit pathogenesis in several different anatomic contexts, and the far-reaching aspects of hostpathogen interaction that underlie the process in each case, has expanded enormously since that time as well. Each such expansion in our understanding of the biology and pathobiology of these organisms has further highlighted the ever more pressing need for effective therapeutic strategies to prevent and/or cure chlamydial infections.

The primary message of the present discussion is, of course, that human infections by $C$. trachomatis and C. pneumoniae impose enormous economic and social burdens on societies world-wide, not to mention the considerable human misery associated with Chlamydia-induced diseases. A safe and effective vaccine that targets both organisms is unquestionably the goal toward which we must strive for control, and ultimately eradication, of chlamydial diseases; it would also be advantageous if that vaccine can be targeted to include C. psittaci and the various potentially pathogenic environmental Chlamydia-like organisms. However, no chlamydial vaccine is currently in sight, and thus other strategies for disease control must be undertaken. In the case of genital infections by C. trachomatis, the initial misery, and more importantly the significant long-term consequences on fertility, could be ameliorated in part by putting in place extensive public awareness campaigns to educate target populations concerning the risks of such infections, as mentioned above. Again, extensive surveillance by local health authorities also is required to identify and treat new cases. Also as mentioned above, it is critically important that such screening and eradiation efforts be carefully modulated so as to be congruent with cultural, religious, and social aspects of the specific populations targeted. These disease eradication strategies require financial input of fairly significant proportion, but as with preventative medical measures of all types, "front-loading" the system monetarily to prevent disease will provide significant savings in health care costs later on. In the case of trachoma, the SAFE program described above must continue. However, we contend that the ultimate solution to eradication of trachoma is an economic one. That is, trachoma finally will be completely eliminated from its endemic areas when the governments that control those trachoma-endemic regions allow/promote economic development of those regions, which in turn will engender better conditions of public hygiene. The community-acquired pneumonia caused by C. pneumoniae is perhaps not an enormous clinical problem. In contrast, cardiovascular disease, now recognized as one of the potential long-term sequelae of respiratory infection by this organism, is a significant problem indeed. Thus, as with the situation for $C$. trachomatis, more effective and wide-spread public screening procedures for C. pneumoniae must be developed and implemented; better therapeutic strategies also must be developed to treat infected individuals, particularly those with persistent chlamydial infections. As outlined above, a number of other important human diseases, including sporadic Alzheimer's disease and multiple sclerosis, have been associated with C. pneumoniae infection, but these associations remain to be confirmed; continued basic and related clinical research thus must be supported strongly until clear answers emerge as to other possible sequelae of pulmonary infection with this organism.

Finally, this article has focused exclusively on the economic and human disease consequences of chlamydial infections, but in our view one additional important message can be derived from the present discussion. That message concerns the relative level of sophistication of our understanding of bacterially-induced diseases, and indeed of infectious diseases in general. As we have learned more about the mechanisms employed by Chlamydia to engender disease, it has become clear that for these pathogens the elicitation of acute disease functions in many cases only as a preliminary requirement for establishment of a long-term relationship with the host. Recent studies of other bacterial pathogens suggest that some organisms which are exclusively or primarily human pathogens also use their acute disease states in various ways to establish chronic infections. The realization that bacterial pathogenesis often is more complex, subtle, and far-reaching than previously understood is forcing some reassessment in the scientific community of how we should approach development of anti-microbials, and how new therapeutic strategies might be envisioned and approached. The result of that reassessment should be more effective means for physicians to combat not only infections by Chlamydia, but also those of other important human bacterial pathogens.

\section{Acknowledgments}

The writing of this article was supported by grants AR-42541 and AI-44055 (A.P.H.) and AI-48331 (J.A.W.-H.) from the US National Institutes of Health. 


\section{References}

Alves, A.P., Medina, N.H., Cruz, A.A., 2002. Trachoma and ethnic diversity in the upper Rio Negro Basin of Amazonas State, Brazil, Ophthal. Epidemiol., 9, 29-34.

Amato, M.P., Battaglia, M.A., Caputo, D., Fattore, G., Gerzeli, S., Pitaro, M., Reggio, A., Trojano, M.; Mu.S.I.C. Study Group, 2002. The costs of multiple sclerosis: a cross-sectional, multicenter cost-of-illness study in Italy, J. Neurol., 249, 152-163.

Anttila, T., Saikku, P., Koskela, P., Bloigu, A., Dillner, J., Ikaheimo, I., Jellum, E., Lehtinen, M., Lenner, P., Hakulinen, T., Narvanen, A., Pukkala, E., Thoresen, S., Youngman, L., Paavonen, J., 2001. Serotypes of Chlamydia trachomatis and risk for development of cervical squamous cell carcinoma, J. Am. Med. Assn., 285, 47-51.

Balin, B.J., Gérard, H.C., Arking, E.J., Appelt, D.M., Branigan, P.J., Abrams, J.T., Whittum-Hudson, J.A., Hudson, A.P., 1998. Identification and localization of Chlamydia pneumoniae in the Alzheimer's brain, Med. Microbiol. Immunol., 187, 23-42.

Beeri, M.S., Werner, P., Adar, Z., Davidson, M., Noy, S., 2002. Economic cost of Alzheimer's disease in Israel, Alzheimer Dis. Assoc. Disord., 16, 73-80.

Belland, R.J., Ouellette, S.P., Gieffers, J., Byrne, G.I., 2004. Chlamydia pneumoniae and atherosclerosis, Cell. Microbiol., 6, 117-127.

Campbell, L.A., Kuo, C.C., 2004. Chlamydia pneumoniae - an infectious risk factor for atherosclerosis, Nat. Rev. Microbiol., 2, 23-32.

Carter, J.D., Valeriano, J., Vasey, F.B., 2004. Doxycycline vs. doxycycline and rifampin in undifferentiated spondyloarthropathy, with special reference to Chlamydia-induced arthritis. A prospective, randomized 9-month comparison, J. Rheumatol., 31, 1973-1980.

CDC website: www.cdc.gov/ncidod/dbmd/diseaseinfo/ chlamydiapneumoniae

Centers for Disease Control and Prevention, 2004. Sexually transmitted disease surveillance 2003 supplement, Chlamydia prevalence monitoring project annual report 2003, Atlanta, GA, US Department of Health and Human Services, Centers for Disease Control and Prevention.

Chesson, H.W., Blandford, J.M., Gift, T.L., Tao, G., Irwin, K.L., 2004. The estimated direct medical cost of sexually transmitted diseases among American youth, 2000, Perspect. Sex. Reprod. Health, 36, 11-19.

Ciervo, A., Petrucca, A., Cassone, A., 2003. Identification and quantification of Chlamydia pneumoniae in human atherosclerotic plaques by LightCycler real time PCR, Mol. Cell. Probes., 17, 107-111.

Clementsen, P., Permin, H., Norn, S., 2002. Chlamydia pneumoniae infection and its role in asthma and chronic obstructive pulmonary disease, J. Investigat. Allergol. Clin. Immunol., 12, 73-79.

Corsaro, D., Valassina, M., Venditti, D., 2003. Increasing diversity with Chlamydia, Crit. Rev. Microbiol., 29, 37-78.

Corsaro, D., Venditti, D., 2004. Emerging chlamydial infections, Crit. Rev. Microbiol., 30, 75-106.

Debattista, J., Martin, P., Jamieson, J., Crane, K., Dolton, I., Russell-Hall, S., DeSilva, J., Hargrave, R., Robinson, T., Ryan, N., Mortlock, M., 2002. Detection of Chlamydia trachomatis in an Australian high school student population, Sex. Transm. Dis., 78, 194-197.
Fox, P.J., Kohatsu, N., Max, W., Arnsberger, P., 2001. Estimating the costs of caring for people Alzheimer's disease in California: 2000-2040, J. Publ. Health Policy, 22, 88-97.

Frick, K.D., Arantxa-Colchero, M., Dean, D., 2004. Modeling the economic net benefit of a potential vaccination program against ocular infection with Chlamydia trachomatis, Vaccine, 22, 690-697.

Garbino, J., Sommer, R., Gerber, A., Regamey, C., Vernazza, P., Genne, D., Dur, P., Rothen, M., Unger, J.P., Lew, D., 2002. Prospective epidemiologic survey of patients with community acquired pneumonia requiring hospitalization in Switzerland, Int. J. Infect. Dis., 6, 288-293.

Gérard, H.C., Branigan, P.J., Balsara, G.R., Heath, C., Minassian, S.S., Hudson, A.P., 1998. Viability of Chlamydia trachomatis in fallopian tubes of patients with ectopic pregnancy, Fertil. Steril., 70, 945-948.

Gerbase, A.C., Mertens, T.E., 1998. Sexually transmitted diseases in Africa: a time for action, Afr. Health, 20, 10-12.

Gerbase, A.C., Rowley, J.T., Heymann, D.H., Berkley, S.F., Piot, P., 1998. Global prevalence and incidence estimates of selected curable STDs, Sex. Transm. Infect., 74 (suppl. 1), S12S16.

Grayston, J.T., 1992. Chlamydia pneumoniae, strain TWAR pneumonia, Annu. Rev. Med., 43, 317-323.

Grayston, J.T., Kronmal, R.A., Jackson, L.A., Parisi, A.F., Muhlestein, J.B., Cohen, J.D., Rogers, W.J., Crouse, J.R., Borrowdale, S.L., Schron, E., Knirsch, C. for the ACES investigators, 2005. Azithromycin for the secondary prevention of coronary events, N. Engl. J. Med., 352, 1637-1645.

Greub, G., Mege, J.-L., Raoult, D., 2003a. Parachlamydia acanthamoebae enters and multiplies within human macrophages and induces their apoptosis, Infect. Immun., 71, 5979-5985. Erratum: 2004, Infect. Immun., 72, 621.

Greub, G., Boyadjiev, I., LaScola B., Raoult, D., Martin C., 2003b. Serological hint suggesting that Parachlamydiaceae are agents of pneumonia in polytraumatized intensive care patients, Ann. N.Y. Acad. Sci., 990, 311-319.

Grio, R., Latino, M.A., Leotta, E., Smirne, C., Lanza, A., Spagnolo, E., Perozziello, A., Caneparo, A., Bello, L., Lerro, R., 2004. Sexually transmitted diseases and pelvic inflammatory disease, Minerva Ginecol., 56, 141-147.

Groot, W., Van Den Brink, H.M., Plug, E., 2004. Money for health: the equivalent variation of cardiovascular diseases, Health Econ., 13, 850-872.

Guaschino, S., De Seta, F., 2000. Update on Chlamydia trachomatis, Ann. N.Y. Acad. Sci., 900, 293-300.

Hahn, D.L., Azenabor, A.A., Beatty, W.L., Byrne, G.I., 2002. Chlamydia pneumoniae as a respiratory pathogen, Front. Biosci., 7, e66-e76.

Hatch, T.P., 1999. Developmental biology, in Stephens, R.S. (Ed.), Chlamydia - Intracellular biology, Pathogenesis, and Immunity, Washington DC, ASM Press.

Heddema, E.R., Kraan, M.C., Buys-Bergen, H.E., Smith, H.E., Wertheim-van Dillem, P.M., 2003. A woman with a lobar infiltrate due to psittacosis detected by polymerase chain reaction, Scan. J. Infect. Dis., 35, 422-424.

Hogan, R.J., Mathews, S.A., Mukjopadhyay, S., Summersgill, J.T., Timms, P., 2004. Chlamydial persistence: beyond the biphasic paradigm, Infect. Immun., 72, 1843-1855.

Honey, E., Templeton, A., 2002. Prevention of pelvic inflammatory disease by control of C. trachomatis infection, Int. J. Gynaecol. Obstet., 78, 257-261. 
Hook, E.W., Peeling, R.W., 2004. Syphilis control - a continuing challenge, N. Engl. J. Med., 351, 122-124.

Howell, M.R., Gaydos, J.C., McKee, K.T., Quinn, T.C., Gaydos, C.A., 1999. Control of Chlamydia trachomatis infections in female army recruits: cost-effective screening and treatment in training cohorts to prevent pelvic inflammatory disease, Sex. Transm. Dis., 26, 519-526.

Ito, I., Ishida, T., Mishima, M., Osawa, M., Arita, M., Hashimoto, T., Kishimoto, T., 2002. Familal cases of psittacosis: possible person-to-person transmission, Intern. Med., 41, 580-583.

Johnsen, S., Birkebaek, N., Andersen, P.L., Emil C., Jensen J.S., Ostergaard, I., 2005. Indirect immunofluorescence and real time PCR for detection of Simkania negevensis in Danish adults with persistent cough and in healthy controls, Scand. J. Infect. Dis., 37, 251-255.

Joyee, A.G., Thyagarajan, S.P., Rajendran, P., Hari, R., Balakrishnan, P., Jeyaseelan, L., Kurien, T., and the STD Study Group, 2004. Chlamydia trachomatis genital infection in an apparently healthy adult population of Tamil Nadu, India: a population-based study, Int. J. STD AIDS, 15, 51-55.

Kahane, S., Platzner, N., Dvoskin, B., Itzhaki, A., Friedman, M.G., 2004. Evidence for the presence of Simkania negevensis in drinking water and in reclaimed wastewater in Israel, Appl. Environ. Microbiol., 70, 3346-3351.

Kalayoglu, M.V., Byrne, G.I., 1998a. Induction of macrophage foam cell formation by Chlamydia pneumoniae, J. Infect. Dis., $177,172-179$.

Kalayoglu, M.V., Byrne, G.I., 1998b. A Chlamydia pneumoniae component that induces macrophage foam cell formation is chlamydial lipopolysaccharide, Infect. Immun., 66, 50675072.

Kasi, P.M., Gilani, A.I., 2004. Trachoma still ignored in developing countries, Lancet, 363, 1736 (letter).

Keefover, R.W., 1996. The clinical epidemiology of Alzheimer's disease, Neurol. Clin., 14, 337-351.

Kelly, A.M., Ireland, M., Aughey, D., 2004. Pelvic inflammatory disease in adolescents: high incidence and recurrence rates in an urban teen clinic, J. Pediatr. Adolesc. Gynecol., 17, 383388.

Krause, W., Bohring, C., 2003. Male infertility and genital chlamydial infection: victim or perpetrator?, Andrologia, 25, 209-216.

Kumaresan, J.A., Mecaskey, J.W., 2003. The global elimination of trachoma: progress and promise, Am. J. Trop. Med. Hyg., 69(5 suppl.), 24-28.

LaMontagne, D.S., Fenton, K.A., Randall, S., Anderson, S., Carter, P. 2004. Establishing the National Chlamydia Screening Programme in England: results from the first full year of screening, Sex. Transm. Infect., 80, 335-341.

Leinonen, M., 1993. Pathogenic mechanisms and epidemiology of Chlamydia pneumoniae, Eur. Heart J., 14 (suppl. K), 57-61.

Lin, T.M., Kuo, C.C., Chen, W.J., Lin, F.J., Eng, H.L., 2004. Seroprevalence of Chlamydia pneumoniae infection in Taiwan, J. Infect. Dis., 48, 91-95.

Loeb, M.B., Molloy, D.W., Smieja, M., Standish, T., Goldsmith, C.H., Mahony, J., Smith, S., Borrie, M., Decoteau, E., Davidson, W., McDougall, A., Gnarpe, J., O’Donnell, M., Chernesky, M., 2004. A randomized controlled trial of doxycycline and rifampin for patients with Alzheimer's disease, J. Am. Geriatr. Soc., 52, 381-387.

Longbottom, D., 2003. Chlamydial vaccine development, J. Med. Microbiol., 52, 537-540.
Mabey, D.C., Solomon, A.W., Foster, A., 2003. Trachoma, Lancet, 362, 223-229.

Mårdh, P.-A., 2004a. Tubal factor infertility, with special regard to chlamydial salpingitis, Curr. Opin. Infect. Dis., 17, 49-52.

Mårdh, P.-A., 2004b. Surveillance - what we know and do not know about the spread of infections by Chlamydia trachomatis, in Deák, J. (Ed.), Proceedings of the Fifth Meeting of the European Society for Chlamydia Research, Budapest (Hungary), Pauker Nyomdaipari Kft.

Marrie, T.J., Peeling, R.W., Reid, T., DeCarolis, E.; Canadian Community Acquited Pneumonia Investigators, 2003. Chlamydia species as a cause of community acquired pneumonia in Canada, Eur. Respir. J., 21, 779-784.

Masata, J., Drazdaková, M., Hruba, D., Rezacova, J., 2004. Prevalence of genital chlamydial infections among young females in Prague, in Deák, J. (Ed.) Proceedings of the Fifth Meeting of the European Society for Chlamydia Research, Budapest (Hungary), Pauker Nyomdaipari Kft.

Maza, L.M. de la, Peterson, E.M., 2002. Vaccines for Chlamydia trachomatis infections, Curr. Opin. Investig. Drugs, 3, 980-986.

Michelow, I.C., Olsen, K., Lozano, J., Rollis, N.K., Duffy, L.B., Ziegler, T., Kauppila, J., Leinonen, M., McCracken, G.H., 2004. Epidemiology and clinical characteristics of community acquired pneumonia in hospitalized children, Pediatrics, 113, 701-707.

Miranda, A.E., Szwarcwald, C.L., Peres, R.L., Page-Shafer, K., 2004. Prevalence and risk behaviors for chlamydial infection in a population-based study of female adolescents in Brazil, Sex. Transm. Dis., 31, 542-546.

Moazed, T.C., Kuo, C.C., Grayston, J.T., Campbell, L.A., 1998. Evidence of systemic dissemination of Chlamydia pneumoniae via macrophages in the mouse, J. Infect. Dis., 177, 13221325.

Molano, M., Weiderpass, E., Posso, H., Morre, S.A., Ronderos, M., Franceschi, S., Arslan, A., Meijer, C.J., Monoz, N., van den Brule, A.J., and the HPV Study Group, 2003. Prevalence and determinants of Chlamydia trachomatis infections in women from Bogota, Columbia, Sex. Transm. Infect., 79, 474-478.

Moxon, R., Rappuoli, R., 2002. Bacterial pathogen genomics and vaccines, Br. Med. Bull., 62, 45-58.

Nusbaum, M.R., Wallace, R.R., Slatt, L.M., Dondrad, E.C., 2004. Sexually transmitted infections and increased risk of co-infection with human immunodeficiency virus, J. Am. Osteopath. Assn., 104, 527-535.

Parish, W.L., Laumann, E.O., Cohen, M.S., Pan, S., Zheng, H., Hoffman, I., Wang, T., Ng, K.H., 2003. Population-based study of chlamydial infection in China: a hidden epidemic, J. Am. Med. Assn., 289, 1265-1273.

Powell, J., O'Connor, C., O'hlarlaithe, M., Saunders, J., DeFreitas, J., 2004. Chlamydia trachomatis prevalence in men in the mid-west of Ireland, Sex. Transm. Infect., 80, 349-353.

Ragonese, P., Salemi, G., D'Amelio, M., Gammino, M., Aridon, P., Savettieri, G., 2004. Multiple sclerosis in southern Europe : Monreale City, Italy. A twenty year followup incidence and prevalence study, Neuroepidemiology, 23, 306-309.

Rich, E., Hook, E.W., Alarcon, G.S., Moreland, L.W., 1996. Reactive arthritis in patients attending an urban sexually transmitted disease clinic, Arthritis Rheum., 39, 1172-1177.

Rigaud, A.-S., Fagnani, F., Bayle, C., Latour, F., Traykov, L., Forette, F., 2003. Patients with Alzheimer's disease living at 
home in France: costs and consequences of the disease, $J$. Geriatr. Psychiatry Neurol., 16, 140-145.

Saikku, P., Leinonen, M., Mattila, K., Ekman, M.R., Nieminen, M.S., Makela, P.H., Huttunen, J.K., Valtonen, V., 1988. Serological evidence of an association of a novel Chlamydia, TWAR, with chronic coronary heart disease and acute myocardial infarction, Lancet, 2, 983-986.

Sarasoja, T., Wikstrom, J., Paltamaa, J., Hakama, M., Sumelahti, M.L., 2004. Occurrence of multiple sclerosis in central Finland: a regional and temporal comparison during 30 years, Acta Neurol. Scand., 110, 331-336.

Schachter, J., 1999. Infection and disease epidemiology, in Stephens, R.S. (Ed.), Chlamydia: Intracellular Biology, Pathogenesis, and Immunity, Washington DC, ASM Press.

Schmidt, S.M., Muller, C.E., Krechting, M., Wiersbitzky, H., Gurtler, L., Wiersbitzky, S.K., 2003. Chlamydia pneumoniae carriage and infection in hospitalized children with respiratory tract diseases, Infection, 31, 410-416.

Shimizu, C., Nabeshima, S., Kikuchi, K., Furusyo, N., Kashiwagi, S., Hayashi, J., 2002. Prevalence of antibody to Chlamydia pneumoniae in residents of Japan, the Solomon Islands, and Nepal, Am. J. Trop. Med. Hyg., 67, 170-175.

Smith, K.A., Bradley, K.K., Stobierski, M.G., Tengelsen, L.A., National Association of State Public Health Veterinarians Psittacosis Compendium Committee, 2005. Compendium of measures to control Chlamydophila psittaci (formerly Chlamydia psittaci) infection among humans (psittacosis) and pet birds, J. Am Vet. Med. Assoc., 226, 532-539.

Soderlin, M.K., Borjesson, O., Kautianen, H., Skogh, T., Leirisalo-Repo, M., 2002. Annual incidence of inflammatory joint diseases in a population based in southern Sweden, Ann. Rheum. Dis., 61, 911-915.

Sriram, S., Stratton, C.W., Yao, S., Tharp, A., Ding, L., Bannan, J.D., Mitchell, W.M., 1999. Chlamydia pneumoniae infection of the central nervous system in multiple sclerosis, Ann. Neurol., 46, 6-14.

Swanborg, R.H., Whittum-Hudson, J.A., Hudson, A.P., 2003. Infectious agents and multiple sclerosis - are human herpes virus 6 and Chlamydia pneumoniae involved?, J. Neuroimmunol., 136, 1-8.

Taylor, H.R., 2001. Trachoma in Australia, Med. J. Aust., 175, 371-372.

Telfer, B.L., Moberley, S.A., Hort, K.P., Branley, J.M., Dwyer, D.E., Muscatello, D.J., Correll, PIK., England, J., McAunlty, J.M., 2005. Probable psittacosis outbreak linked to wild birds, Emerg. Infect. Dis., 11, 391-397.

Tobin, J.M., Harindra, V., Mani, R., 2004. Which treatment for genital tract Chlamydia trachomatis infection?, Int. J. STD AIDS, 15, 737-739.

Reçu le 10 avril 2005. Accepté le 30 juin 2005.
Villareal, C., Whittum-Hudson, J.A., Hudson, A.P., 2002. Persistent Chlamydiae and chronic arthritis, Arthritis Res., $4,5-9$.

Ward, M.E., 1999. Mechanisms of Chlamydia-induced pathogenesis, in Stephens, R.S. (Ed.), Chlamydia - Intracellular biology, Pathogenesis, and Immunity, Washington DC, ASM Press.

Watts, S., 1997. Epidemics and History, Disease, Power, and Imperialism, New Haven, Ct, Yale University Press.

West, S.K., 2004. Trachoma: new assault on an ancient disease, Prog. Ret. Eye Res., 23, 381-401.

Whittum-Hudson, J.A., 1999. Prevention vs. treatment of Chlamydial infections: A novel experimental approach, Curr. Treatment Options Infect. Dis., 1, 88-92.

Whittum-Hudson, J.A., 2005. Ocular chlamydial infections, in Zierhut, M., Stern, M.E., Sullivan, D.A. (Eds), Immunology of the Lacrimal Gland, Tear Film and Ocular Surface, London, Taylor and Francis.

Whittum-Hudson, J.A., An, L.-L., MacDonald, A.B., Prendergast, R.A., Saltzman, W.M., 1996. Oral immunization with an anti-idiotypic antibody to the exoglycolipid antigen protects against experimental Chlamydia trachomatis infection, Nat. Med., 2, 1116-1121.

Whittum-Hudson, J.A., Rudy, D., Gerard, H., Vora, G., Davis, E., Haller, P.K., Prattis, S.M., Hudson, A.P., Saltzman, W.M., Stuart, E.S., 2001. The anti-Idiotypic antibody to chlamydial glycolipid exoantigen (GLXA) protects mice against genital infection with a human biovar of Chlamydia trachomatis, Vaccine, 19, 4061-4071.

Whittum-Hudson, J.A., Gérard, H.C., Schumacher, H.R., Hudson, A.P., 2004. Chlamydiae and inflammatory arthritis, in Columbus, F. (Ed.), Focus on Arthritis Research, Nova Science Publishers Inc., 175-199.

Whittum-Hudson, J.A., Gérard, H.C., Schumacher, H.R., Hudson, A.P., 2005a. Pathogenesis of Chlamydia-associated arthritis, in Bavoil, P., Wyrick, P. (Eds), Chlamydia Pathogenesis and Treatments, Blackwell Publishing, Inc. In press.

Whittum-Hudson, J.A., Schumacher, H.R., Hudson, A.P., 2005b. Chlamydia pneumoniae and inflammatory arthritis, in Yamamoto, Y., Friedman, H., Bendinelli, M. (Eds), Chlamydia pneumoniae Infection and Diseases, New York, Kluwer/Academic Press, 227-238.

Yamaguchi, T., Yamazaki, T., Inoue, M., Mashida, C., Kawagoe, K., Ogawa, M., Shiga, S., Nakagawa, Y., Kishimoto, T., Kurane, I., Ouchi, K., Ohzeki, T., 2005. Prevalence of antibodies against Simkania negevensis in a healthy Japanese population determined by the microimmunofluorescence test, FEMS Immunol. Med. Microbiol., 43, 21-27. 